\title{
Accumulation of nine metals and one metalloid in the tropical scallop Comptopallium radula from coral reefs in New Caledonia
}

\author{
M. Metian ${ }^{a, b}$ P. Bustamante ${ }^{b}$, L. Hédouin ${ }^{a, b, c}$ and M. Warnau ${ }^{a,{ }^{*}}$ \\ a International Atomic Energy Agency - Marine Environment Laboratories, 4 Quai Antoine ler, MC-98000 Monaco \\ ${ }^{\mathrm{b}}$ Centre de Recherche sur les Ecosystèmes Littoraux Anthropisés, UMR 6217, CNRS-IFREMER-Université de La \\ Rochelle, 22 avenue Michel Crépeau, F-17042 La Rochelle Cedex 01, France paco.bustamante@univ-Ir.fr \\ ${ }^{\mathrm{C}}$ IRD-Centre de Nouméa, BP A5, 98848 Nouméa Cedex, New Caledonia
}

*: Corresponding author : Warnau M., Tel.: +377 9797 72 58; fax: +377 9797 72 76, email address : m.warnau@iaea.org

\begin{abstract}
:
Uptake of waterborne $\mathrm{Cd}, \mathrm{Co}, \mathrm{Mn}$ and $\mathrm{Zn}$ was determined in laboratory experiments using radiotracer techniques $\left({ }^{109} \mathrm{Cd},{ }^{57} \mathrm{Co},{ }^{54} \mathrm{Mn}\right.$ and $\left.{ }^{65} \mathrm{Zn}\right)$. Labelled $\mathrm{Zn}$ was mainly accumulated in the digestive gland $(65 \%)$ and $\mathrm{Co}$ in kidneys (81\%); $\mathrm{Cd}$ and $\mathrm{Mn}$ were similarly distributed in digestive gland and gills. In a complementary field study, $\mathrm{Ag}, \mathrm{As}, \mathrm{Cd}, \mathrm{Co}, \mathrm{Cr}, \mathrm{Cu}, \mathrm{Fe}, \mathrm{Mn}, \mathrm{Ni}$, and $\mathrm{Zn}$ were analysed in scallops collected at two stations showing different contamination levels. Digestive gland and kidneys displayed the highest concentrations. Ag, As, Cd, and Fe differed in soft tissues from the two stations, suggesting that Comptopallium radula could be a valuable local biomonitor species for these elements. Low $\mathrm{Mn}$ and $\mathrm{Zn}$ concentrations found in kidneys suggest that their content in calciumphosphate concretions differs from the other pectinids. Preliminary risk considerations suggest that As would be the only element potentially leading to exposure of concern for seafood consumers.
\end{abstract}

This study investigates metal accumulation behaviour in the tropical scallop Comptopallium radula and preliminary risk assessment for consumers.

Keywords: Tropical environment; Trace elements; Arsenic; Radiotracers; Pectinidae; Risk assessment; Bioindicator species 


\section{$\underline{\text { Introduction }}$}

The urban and industrial expansion in tropical coastal zones increases the release of contaminants which can constitute a threat to local marine ecosystems and globally affect marine diversity (Peters et al. 1997). The SW lagoon of New Caledonia (South Pacific Ocean) represents a tropical case study as it is subject to large inputs of heavy metals mainly due to intense land-based mining activities (Ambastian et al. 1997). New Caledonia is the third largest producer of nickel $(\mathrm{Ni})$ in the world and metal contamination mainly concerns $\mathrm{Ni}$ and its mining by-product such as cobalt (Co), chromium (Cr) and manganese $(\mathrm{Mn})$ which occur at elevated concentrations in $\mathrm{Ni}$ ores. Furthermore, the city of Noumea produces sewage sludge, which can also lead to metal contamination in the surrounding lagoon. Nevertheless, published information about the contamination status of the New Caledonia marine environment is extremely scarce (Labrosse et al. 2000) and limited to a narrow range of species (Bustamante et al. 2000; Hédouin et al. 2007; Monniot et al. 1994). Environmental studies are therefore needed to understand the behaviour and fate of metals in this area in order to develop a program of coastal zone monitoring and improve local marine resource management.

The use of biomonitor species to examine metal contamination is a powerful tool to reveal the bioavailability of the considered contaminants (e.g. Rainbow and Phillips 1993). In this respect, bivalves have been extensively used as biomonitor species because of their high capacity to bioaccumulate various contaminants (see e.g. Goldberg 1995; Rainbow 1995). Among bivalves, scallops have been shown to concentrate various trace elements to a large extent (e.g. Bryan 1973; Bustamante and Miramand 2005; Uthe and Chou 1987), even in remote areas such as Antarctica that are non subject to direct anthropogenic inputs (Berkman and Nigro 1992; Mauri et al. 1990; Viarengo et al. 1993). 
Within the huge bivalve stock in New Caledonia, exhibiting around 1200 species among the whole 8000 bivalve species estimated in the world (Bouchet 1979), 30 pectinid species have been described to date (Dijkstra et al. 1990). In the SW lagoon, Comptopallium radula appears relatively common and constitutes, with Mimachlamys gloriosa and Brachtechlamys vexillum the major species targeted for human consumption. Whereas information on stock, reproduction and taxonomy of these scallops is available (Dijkstra et al. 1990; Lefort 1994), to the best of our knowledge, no study on the bioaccumulation of trace elements in the soft tissues of New Caledonian scallops has been published to date.

The aim of this study was therefore to examine the bioaccumulation and tissue distribution of a wide range of trace elements in the scallop C. radula using both laboratory experiments under controlled conditions and in situ investigations. Firstly, the uptake kinetics of 4 selected radiotracers $\left({ }^{109} \mathrm{Cd},{ }^{57} \mathrm{Co},{ }^{54} \mathrm{Mn}\right.$, and $\left.{ }^{65} \mathrm{Zn}\right)$ and their body distribution were determined following seawater exposure. Secondly, 1 metalloid (As) and 9 metals (Ag, $\mathrm{Cd}, \mathrm{Co}, \mathrm{Cr}, \mathrm{Cu}$, $\mathrm{Fe}, \mathrm{Mn}, \mathrm{Ni}$, and $\mathrm{Zn}$ ) were analysed in the tissues of scallops from reference and contaminated sites in order to evaluate the bioaccumulation capacities of $C$. radula and its potential as a biomonitor species for trace element contamination. Finally, the human risk link to scallop consumption is discussed.

\section{Material and Methods}

\section{Radiotracer experiments}

Twenty scallops (Comptopallium radula [Linnée, 1758]) were collected in the vicinity of Noumea City (i.e. Sainte Marie Bay) by SCUBA diving in October 2004. The organisms (76 $\pm 3 \mathrm{~mm}$ length) were experimentally exposed to four radiotracers $\left({ }^{109} \mathrm{Cd},{ }^{57} \mathrm{Co},{ }^{54} \mathrm{Mn}\right.$, and ${ }^{65} \mathrm{Zn}$ ) via seawater. Seawater was spiked with low nominal activities of each selected radiotracer: $1.76 \mathrm{kBq} \mathrm{l}^{-1}{ }^{109} \mathrm{Cd}, 0.91 \mathrm{kBq} \mathrm{l}^{-1}{ }^{57} \mathrm{Co}, 0.65 \mathrm{kBq} \mathrm{l}^{-1}{ }^{54} \mathrm{Mn}, 0.65 \mathrm{kBq} \mathrm{l^{-1 }}{ }^{65} \mathrm{Zn} . . \mathrm{In}$ terms of stable metal concentration, these additions corresponded to $910^{-3} \mathrm{ng} \mathrm{Cd} \mathrm{l}^{-1}, 610^{-3} \mathrm{ng}$ 
$\mathrm{Co}^{-1}, 510^{-2} \mathrm{ng} \mathrm{Mn} 1^{-1}$ and, $410^{-3} \mathrm{ng} \mathrm{Zn} 1^{-1}$, which are 1 to 5 orders of magnitude lower than the background concentrations of these metals in open seas (Bruland 1983).

The uptake of the radiotracers was followed during four days using gamma spectrometric techniques. Uptake kinetics were expressed as change in concentration factor (CF; ratio between activity of the radiotracer in the whole soft tissues or in a body compartment $-\mathrm{Bq} \mathrm{g}^{-1}$ wet wt- and time-integrated activity of radiotracer in seawater $-\mathrm{Bq}^{-1}-$ ) according to time. Radiotracer uptake kinetics were described using a simple linear regression model

$\mathrm{CF}_{\mathrm{t}}=\mathrm{k}_{\mathrm{u}} \mathrm{t}$

where $\mathrm{CF}_{\mathrm{t}}$ is the concentration factor at time $\mathrm{t}(\mathrm{d})$ and $\mathrm{k}_{\mathrm{u}}$ is the uptake rate constant $\left(\mathrm{d}^{-1}\right)$ (Whicker \& Schultz 1982).

At various time intervals $(12 \mathrm{~h}, 30 \mathrm{~h}, 48 \mathrm{~h}, 72 \mathrm{~h}$, and $96 \mathrm{~h}$ ), four individuals were randomly sampled and dissected in order to determine the tissue distribution of the elements. Shells, digestive gland, kidneys, gills, gonad, adductor muscle and the remaining soft tissues were separated and counted using a high-resolution $\gamma$-spectrometry system consisting of 4 coaxial Ge (N- or P-type) detectors (EGNC 33-195-R, Canberra ${ }^{\circledR}$ and Eurysis ${ }^{\circledR}$ ) connected to a multichannel analyzer and a computer equipped with a spectra analysis software (Interwinner $\left.{ }^{\circledR} 6\right)$. The radioactivity of the samples was determined by comparison with standards of known activities and appropriate geometries and was corrected for background and physical decay of the radiotracers. Counting times were adapted to obtain counting rates with relative propagated errors lower than $5 \%$.

\section{Trace element analyses}

Ten scallops were collected by SCUBA diving in October 2004 in the southern New Caledonian lagoon in two bays showing different physico-chemical specificities (Fig. 1): Maa Bay ( $\mathrm{n}=5 ; 76 \pm 6 \mathrm{~mm}$ length) and Sainte Marie Bay ( $\mathrm{n}=5 ; 77 \pm 2 \mathrm{~mm}$ length). This last site, located to the East of Noumea, is characterized by elevated inputs of sewage sludge (Jaquet 
2005). Moreover terrigenous inputs due the open casting mining are released by the Coulée River and deposited along the shoreline, reaching areas as distant as Sainte Marie Bay (Fernandez et al. 2006). Conversely, the Maa Bay is located $20 \mathrm{~km}$ North-West of Noumea and is considered to be exempt from direct anthropogenic inputs of metals and the area is sparsely inhabited. Moreover, the Maa Bay is not surrounded by lateritic soils (viz. a typical source of metal contamination by natural erosion) and is therefore considered as a noncontaminated "reference" site in this study.

In order to verify the contamination level of the two locations, sediments were collected by SCUBA diving in parallel to organisms. Sediments were stored in acid-washed and hermetically sealed plastic bag until return to the laboratory.

Upon arrival to the laboratory, organisms were depurated for $24 \mathrm{~h}$ in clean seawater aquaria to remove pseudo-faecal and faecal material from the digestive tract. Each individual was measured and weighed prior to dissection: the digestive gland, kidneys, gills, gonads and adductor muscle were carefully removed from each individual. The remaining tissues were also taken into account in order to calculate the whole metal content of the organisms.

All samples (scallop tissues and sediments) were dried for several days at $60^{\circ} \mathrm{C}$ until they reached a constant weight. Then, sediments were sieved on a $1 \mathrm{~mm}$ meshed sieve in order to eliminate heterogeneous materials (e.g. stones, fragment of corals) prior to elemental analysis. Aliquots of the samples ranging from 50 to $300 \mathrm{mg}$ were digested using a 3:1 (v:v) nitrichydrochloric acid mixture with $65 \% \mathrm{HNO}_{3}$ (Merck, suprapur quality) and 70\% $\mathrm{HCl}$ (Merck, suprapur quality). Acidic digestion was performed overnight under ambient temperature and then heated in a microwave during 30 min with increasing temperature until $105^{\circ} \mathrm{C}$, and 15 min at $105^{\circ} \mathrm{C}(1200 \mathrm{~W})$. After the mineralization process, each sample was diluted to 30 or $50 \mathrm{ml}$ with milli-Q quality water, according to the volume of acid added to the mineralization (3 $\mathrm{ml}$ or $4.5 \mathrm{ml})$.

$\mathrm{Ag}, \mathrm{As}, \mathrm{Cd}, \mathrm{Co}, \mathrm{Cr}, \mathrm{Cu}, \mathrm{Fe}, \mathrm{Mn}, \mathrm{Ni}$ and $\mathrm{Zn}$ were analysed either by ICP-OES (Varian ${ }^{\circledR}$ VistaPro) or ICP-MS (Varian ${ }^{\circledR}$ Ultra Mass 700). Reference tissues (dogfish liver DOLT-3, NRCC, 
and lobster hepatopancreas TORT-2, NRCC) were treated and analysed in the same way as the samples. Results were in good agreement with the certified values, and the standard deviations were low, proving good repeatability of the method. The results for standard reference materials displayed recoveries of the elements ranging from $79 \%$ to $122 \%(\mathrm{n}=10)$. For each set of analyses, blanks were included in each analytical batch. The detection limits $\left(\mu \mathrm{g} \mathrm{g}^{-1}\right.$ dry wt) for ICP-OES were $10.1(\mathrm{As}), 0.8(\mathrm{Cr}), 0.5(\mathrm{Cu}), 0.3(\mathrm{Fe}), 0.04(\mathrm{Mn}), 1.1(\mathrm{Ni})$ and $0.7(\mathrm{Zn})$ and for ICP-MS, they were $0.1(\mathrm{Ag}), 0.3(\mathrm{Cd}), 0.03(\mathrm{Co})$. All metal concentrations are given on a dry weight basis ( $\mu \mathrm{g} \mathrm{g}^{-1}$ dry wt).

\section{3.:Preliminary risk assessment for consumers}

A maximum recommended consumption of scallops was evaluated on the basis of the Provisional Maximum Tolerable Daily Intake (PMTDI) or Provisional Tolerable Weekly Intake (PTWI) given by the Joint Expert Committee on Food Additives (http://www.inchem.org/pages/jecfa.html).

In this calculation, metal sources supplied by other meals or by drinking water in the same day were not taken into account, i.e. only metal intake coming from the scallop meal has been considered. The PMTDI for $\mathrm{Cu}, \mathrm{Fe}$, and Zn are respectively 500, 800 and $1000 \mu \mathrm{g} \mathrm{kg}^{-1} \mathrm{~d}^{-1}$ and PTWI for As and Cd are 15 and $7 \mu \mathrm{g} \mathrm{kg}^{-1} \mathrm{wk}^{-1}$ (JECFA 2006; WHO 1989). The calculation was done for $\mathrm{As}, \mathrm{Cd}, \mathrm{Cu}, \mathrm{Zn}$ and $\mathrm{Fe}$ by dividing the load $(\mu \mathrm{g})$ of each element measured in whole soft parts or in the adductor muscle (for both sites) by the respective PMTDI or PTWI and by a consumer average body weight (viz. $50 \mathrm{~kg}$ and $80 \mathrm{~kg}$ body weight for female and male human, respectively). In this manner, results indicated the maximum number of consumed $C$. radula not to exceed. Although $C$. radula is generally eaten whole, both whole soft parts and the adductor muscle alone were considered in the risk calculations for comparison purpose (viz., the adductor muscle is the only tissue eaten in the most usually marketed scallop species). 


\section{Data treatment}

Statistical analyses of the data were performed by 1- or 2-way ANOVA, followed by the multiple comparison test of Tukey. The variability explained by each factor was derived from the sum of squares (Warnau et al. 1998). After verification of the variance homogeneity, 2way analysis of variance (ANOVA) was used with sampling location and body compartment as fixed factors. When the homogeneity hypothesis was rejected by ANOVA, a multiple comparison test of Tukey was carried out to assess the most significant impact levels in the examined stations, and then the most significant metal concentrations in the body compartments. Comparison of data expressed as percentages (body distribution) was carried out after arcsine transformation of the data in respect with basic normality requirements of parametric tests (Zar 1996).

Concerning radiotracer data analyses, kinetics of metal uptake in scallops were fitted using linear regression routines (Statistica ${ }^{\circledR} 6$ ). The best fit of the different regressions was selected by examination of residuals and $\mathrm{R}^{2}$. Linearity of the kinetics was tested by the linearity test for regression with replication (Zar 1996).

The level of significance for statistical analyses was always set at $\alpha=0.05$.

\section{$\underline{\text { Results }}$}

\section{Laboratory experiments: radiotracer uptake stududy}

The bioaccumulation kinetics of the 4 radiotracers in the whole soft parts of $C$. radula were best fitted by a linear model (Fig. 2). The uptake rate constants $\left(\mathrm{k}_{\mathrm{u}}\right)$ found for the studied radiotracers rank as follows: $\mathrm{Mn}=\mathrm{Co}<\mathrm{Cd}<\mathrm{Zn}$. After 4 days of exposure, the soft-parts reached concentration factors (CFs) of $62 \pm 14$ for $\mathrm{Cd}, 15 \pm 8$ for Co, $15 \pm 4$ for $\mathrm{Mn}$, and 149 \pm 34 for $\mathrm{Zn}$ (Fig. 2). In addition, CFs were calculated for each organ (Table 1). The latter ones clearly show the contrasting efficiencies of metal accumulation by scallop tissues. Indeed, the highest CF was found in the kidneys for ${ }^{109} \mathrm{Cd}(391 \pm 69)$ and ${ }^{57} \mathrm{Co}(603 \pm 298)$ and in the 
digestive gland for ${ }^{65} \mathrm{Zn}(549 \pm 92)$. In the case of the ${ }^{54} \mathrm{Mn}$, the $\mathrm{CF}$ of gills, kidneys and digestive gland approximately reached the same value $(\sim 30)$ after $4 \mathrm{~d}$ of exposure.

At the end of the exposure period, the distribution of the radiotracers was compared among the scallop body compartments following two steps (Table 2): 1) between the shell and the soft parts 2) among the different tissues and organs constituting the soft parts. Considering the whole scallops, ${ }^{57} \mathrm{Co}$ and ${ }^{54} \mathrm{Mn}$ were mainly (i.e. 92 and $96 \%$, respectively) contained in the shell. Among the soft tissues, ${ }^{54} \mathrm{Mn}$ was mainly associated with the digestive gland (33\%) and the gills $(33 \%)$, whereas kidneys contained most of the ${ }^{57} \mathrm{Co}(65 \%)$. The two other radioisotopes were mainly present in the soft parts $\left(69 \%\right.$ for ${ }^{109} \mathrm{Cd}$ and $58 \%$ for ${ }^{65} \mathrm{Zn}$ ), with $65 \%$ of the soft part ${ }^{65} \mathrm{Zn}$ activity being in the digestive gland whereas ${ }^{109} \mathrm{Cd}$ was mainly present in the gills $(38 \%)$ and the digestive gland (25\%).

\section{In situ analyses}

Arsenic and metal concentrations in the sediment and in the tissues and organs of C. radula collected from the two sampling sites are given in Tables 3 and 4. Except for Ag which concentrations were below the detection limit, sediments from Maa Bay displayed significantly higher elemental concentrations compared to the supposedly more contaminated site of Sainte-Marie Bay (Table 3). In contrast, scallops from Maa Bay showed higher concentrations of $\mathrm{As}, \mathrm{Cd}$, and $\mathrm{Fe}$ in their tissues whereas $\mathrm{Ag}$ was far more concentrated in scallops from Sainte-Marie Bay. Independently of the sampling site, the digestive gland and kidneys of $C$. radula generally showed the highest element concentrations (Table 4). The distribution patterns of elemental concentrations were similar between scallops from both sampling sites except for Ag which specifically accumulated in the digestive gland in Maa Bay and in the kidneys in Sainte Marie Bay.

The body distribution of the different elements among the tissues and organs of the scallops from both sites are compared in Figure 3. The digestive gland clearly exhibited the highest proportion of $\mathrm{Ag}, \mathrm{As}, \mathrm{Cr}, \mathrm{Fe}$ and $\mathrm{Zn}$ in both areas. In the case of $\mathrm{Cd}$ and $\mathrm{Ni}$, the digestive 
gland and kidneys contained most of the metal burden. Regarding $\mathrm{Co}$ and $\mathrm{Cu}$, the major part of the metals was contained in kidneys in Sainte-Marie Bay whereas in Maa Bay, the digestive gland also stored a large fraction of $\mathrm{Co}$ and contained the major part of $\mathrm{Cu}$. In the case of Mn, distribution among tissues and organs is rather homogeneous in scallops from the two bays.

\section{3.:Risk assessment}

The element content in the whole soft parts of the scallops allowed the computation of the number of bivalves to be eaten by male and female Human to reach the PMTDI or, in the case of As and Cd, the PTWI (Table 5). Overall, As appears as the main element of concern regarding the consumption of $C$. radula from both locations since the consumption of 4 (for women) or 8 (for men) scallops would result in exceeding the PTWI threshold. For the other elements, the consumption of more than 40 scallops is necessary to reach the recommended PMTDI or PTWI.

When only the adductor muscle was considered, the associated risk was lower as expected (element concentrations in the muscle were always lower than in whole soft tissues). If any, As was the only element of concern; however 27 adductor muscles for women and 44 for men should be eaten before reaching the PTWI threshold (data not shown). For the other elements, the consumption of more than 374 scallops is necessary to reach the recommended PMTDI or PTWI.

\section{$\underline{\text { Discussion }}$}

Several studies have pointed out the ability of various scallop species to accumulate high levels of trace elements in their tissues (e.g., Bryan 1973; Bustamante and Miramand 2005; Uthe and Chou 1987). Such a bioaccumulation ability does not appear being linked to specific anthropogenic contamination of the environment since scallops from remote areas such as the North Atlantic or the Antarctica were shown to contain elevated Cd concentrations compared 
to related or even identical species from temperate regions (Berkman and Nigro 1992; Bustamante and Miramand 2004; Mauri et al. 1990; Viarengo et al. 1993). Conversely, very few studies have focused on tropical scallops (Francesconi et al. 1993) and the current literature globally lacks related baseline information.

In this work, the bioaccumulation efficiency of trace elements of the tropical scallop Comptopallium radula has been evaluated by comparing individuals collected from two contrasting coastal areas. To assess the difference in the contamination status of both stations, trace elements were analysed in sediments (Table 3). Surprisingly, element concentrations in sediment were high in the reference site (Maa Bay) compared to those from the site close to Noumea City and subject to higher terrigenous inputs (Sainte-Marie Bay). The only exception to this was $\mathrm{Ag}$ which was below the detection limit of the method whereas $\mathrm{Co}, \mathrm{Cr}, \mathrm{Cu}, \mathrm{Mn}, \mathrm{Ni}$ and $\mathrm{Zn}$ concentrations were at least two times higher in the sediment from Maa Bay compared to Sainte-Marie Bay. Even if these results are somewhat surprising, they demonstrate that the two sampling sites are actually contrasting from the point of view of the relative bioavailability of the former elements.

Regarding the levels in $C$. radula, scallop tissues highly concentrated the analysed elements irrespective of the environment, which is consistent with reported data for other pectinid species (e.g., Bryan 1973; Bustamante and Miramand 2004; Mauri et al. 1990; Uthe and Chou 1987). Interestingly, bioconcentration ability of C. radula allowed measuring relatively high levels of elements, even when sediment analysis showed concentrations below detection limit, as it was the case for $\mathrm{Ag}$ (see Tables 3 and 4). Out of the 10 analysed elements, Ag levels were significantly higher $(\mathrm{p}<0.0001)$ in $C$. radula collected in Sainte-Marie Bay whereas As, $\mathrm{Cd}$ and Fe concentrations were higher in scallops from Maa Bay; the other elements did not show significant differences ( $p>0.05$ ) between the two bays.

Silver is a proxy for anthropogenic input in coastal waters due to its high enrichment in sewage sludge from coastal cities (Andren and Bober 2002; Luoma et al. 1995). Hence higher levels of Ag in scallop tissues from Sainte-Marie Bay indicated that this area is subject urban 
pollution which is supporting the results of the modelling approach recently published by Fernandez et al. (2006). Specifically, exposure to high Ag levels in Sainte Marie Bay lead to the accumulation of the metal in the kidneys of $C$. radula rather than in the digestive gland as observed in Maa Bay. In other Pectinidae species, the digestive gland generally exhibits the highest Ag concentrations among soft tissues (Bryan 1973; Bustamante and Miramand 2004, 2005; Segar et al. 1971). To the best of our knowledge, these very different Ag storage strategies of $C$. radula between two sites have never been reported for the Pectinidae family and deserve further investigation.

In contrast to $\mathrm{Ag}$, As has received little attention in pectinids. The levels of this element in the soft parts of $C$. radula were quite high in both bays (i.e. $45 \pm 6$ and $87 \pm 12 \mu \mathrm{g} \mathrm{g}^{-1}$ dry wt in Sainte-Marie Bay and Maa Bay, respectively) which rather contrasts with published data in Pectinidae from temperate zones which display generally much lower concentrations (Bustamante and Miramand 2005; Lai et al. 1999). For example, the variegated scallop Chlamys varia from the Bay of Biscay (France) reached maximum As concentrations of $25 \pm$ $5 \mu \mathrm{g} \mathrm{g}^{-1}$ dry wt in the whole soft parts (Bustamante and Miramand 2005). Bivalves generally display a limited capacity in accumulating As from seawater (e.g. Hédouin 2006; Ünlü and Fowler 1979) and available literature indicates that the high As levels measured in tropical pectinids are probably originating from their diet (see e.g. Neff 1997). Hence, higher As levels in C. radula soft tissues could indicate a high dietary source and/or an elevated bioavailability of As in their environment. Such an hypothesis would be consistent with coastal organic contamination due to agricultural activities and waste discharges from shrimp aquaculture that has been reported for the two bays where $C$. radula was collected (Labrosse et al. 2000; Lemonnier and Faninoz 2006). Indeed, important discharges of N-enriched compounds could locally modify the N:P ratio and as phytoplankton metabolises As more easily in a phosphate-depleted environment (e.g. Smedley and Kinniburgh 2002), this might result in As transfer to filter-feeders and enhanced As bioaccumulation in their tissues (Benson and Summons 1981). Similarly, the higher As concentrations observed in scallops 
from Maa Bay that in Sainte Marie Bay would likely to be due to difference in dietary bioavailability of As between the two areas.

Higher $\mathrm{Cd}$ and $\mathrm{Fe}$ concentrations in C. radula from Maa Bay also support this hypothesis. Indeed, authors generally agree that high Cd concentrations in scallop tissues are related to their intense feeding rates (e.g. Berkman and Nigro 1992; Palmer and Rand 1977) and Fe tends to complex with organic matter or colloids, leading to a high bioavailability to phytoplankton (Chen et al. 2003). Other studies also reported similar results with higher As and/or Cd concentrations in scallop from clean sites compared to contaminated ones (viz. $C$. varia from France, Bustamante and Miramand 2005, and Placopecten magellanicus from Canada, Uthe and Chou 1987). In both cases, these atypical levels were attributed to feeding and nutritional inadequacy of the diet. A further characterization of food composition (stomach content analyses) and/or metal concentrations in the food of the scallop in the sampling areas would be the next step to validate such an assumption. Even if the food seems to be the major accumulation pathway, the contribution of dissolved compartment cannot be neglected. Indeed, radiotracer experiments revealed the relatively high uptake of waterborne ${ }^{109} \mathrm{Cd}$ in scallops, clearly showing that the high accumulation of $\mathrm{Cd}$ would not be only restricted to dietary inputs.

Although not different between the two studied stations, $\mathrm{Co}, \mathrm{Cr}$ and $\mathrm{Ni}$ concentrations measured in the tissues of $C$. radula appear relatively elevated when compared with data from the literature (Bryan 1973; Bustamante and Miramand 2005; Pesch et al. 1977). Some of the variations could account for the specific characteristics of metal accumulation, but high Co, $\mathrm{Cr}$ and $\mathrm{Ni}$ concentrations might rather be due to natural and anthropogenic inputs of these metals in the context of the local geology of New Caledonia since lateritic soils are particularly rich in these 3 very elements (Labrosse et al. 2000). However, the lack of differences in tissues between the two sampling sites was unexpected in regards to sediment results and suggests that the scallops readily accumulate these three metals until a threshold level above which a higher contamination does not affect any longer the levels within $C$. 
radula tissues. Field experiments such as transplantations from relatively clean to strongly contaminated sites would be interesting to validate this hypothesis.

Studies on metal concentrations in the tissues of scallops from various locations around the world have highlighted their common ability to concentrate $\mathrm{Mn}$ and $\mathrm{Zn}$ in the kidneys up to very high levels, typically exceeding $1000 \mu \mathrm{g} \mathrm{g}^{-1}$ dry wt (see Table 6). However, C. radula does not follow this trend (Table 4), and rather behaves as the southern and the northern scallops Adamussium colbecki and Patinopecten yessoensis, respectively (Ishii et al. 1985; Mauri et al. 1990). Although kidney cells of A. colbecki exhibit the same cytoarchitecture as the other Pectinidae, it has been shown that the low renal bioaccumulation capacity for Mn and $\mathrm{Zn}$ in this species was due to the low degree of mineralization of their nephrolithes, viz. the renal phosphate-rich concretions that are well known for their ability to trap and detoxify intracellular metals (George et al. 1980; Nigro et al. 1992). Hence, the atypical low levels of $\mathrm{Mn}$ and $\mathrm{Zn}$ in $C$. radula kidneys might be due to interspecific diversity in the amount and/or degree of mineralization of renal concretions.

The lower $\mathrm{Zn}$ accumulation capacity of the kidneys compared to the digestive gland was also observed in our laboratory experiment: ${ }^{65} \mathrm{Zn}$ concentration factor was far higher in the digestive gland than in kidneys of $C$. radula. Interestingly, Bryan (1973) showed that the Queen scallop Aequipecten opercularis (a scallop presenting typical, highly mineralized renal concretions) concentrated ${ }^{65} \mathrm{Zn}$ to a much higher extent in kidneys than in digestive gland. These observations would support the hypothesis that $C$. radula might have developed an alternative detoxification strategy for $\mathrm{Zn}$ in the digestive gland to compensate the supposedly low mineralization of its renal concretions.

In New Caledonia, C. radula is commonly fished and consumed whole. Therefore, we performed a preliminary risk assessment taking into account the trace element concentrations measured in scallops from the two selected bays. Accordingly, As appears as the only limiting element for human consumption of these scallops. Indeed, consumption of the whole soft parts of 4 to $8 C$. radula during a single week would lead to exceed the PTWI value 
recommended for As by WHO (viz. $15 \mu \mathrm{g} \mathrm{kg}^{-1} \mathrm{wk}^{-1}$; WHO 1989). However, one has to keep in mind that As speciation has not been taken into account in the present computation. Now, it is well known that both bioavailability and toxicity of As largely depend on its chemical speciation (see e.g. Neff 1997; Warnau et al. 2007). Inorganic As species (i.e. arsenite and arsenate), on which is based the PTWI, are the most toxic forms both in terms of acute toxicity and carcinogenicity whilst it is generally reported that marine organisms bioaccumulate the element mainly as organic (e.g., arsenobetaine and arsenosugars) compounds that are not or slightly toxic (ibid.). Since our preliminary computations were made using the concentrations of total As, it is obvious that the actual number of scallops needed to reach As PTWI will be higher than 4 (for women) to 8 (for men). However, it has been shown in several marine species that inorganic As can sometimes represents a high proportion of total As concentrations (see e.g. Fattorini and Regoli 2004; Warnau et al. 2007). Hence, rather than speculating on these values, the present computations should be considered as a warning signal about the very possible threat due to eating large meals composed of these scallops. Although traditional habits are not easily changed, a solution could be to recommend the sole consumption of adductor muscles (as is the case for most other pectinid species) since results showed consuming muscle was a non-risk issue, even without taking into account As speciation, as a minimum of 27 muscles would be needed to reach the As PTWI.

\section{Conclusions}

This work has shown that $C$. radula could be used to biomonitor Ag contamination in the New Caledonian lagoon. For the other elements being accumulated differently between the two sampling sites (i.e. As, $\mathrm{Cd}$, and Fe), the differences between sites seem to reflect the elemental variations in the scallop environment, supporting the use of $C$. radula as a valuable biomonitor species for As, $\mathrm{Cd}$ and Fe contamination. However, additional information has to be collected from the field to understand more precisely the reason of such a difference. Furthermore, the contribution of the different routes of intake (seawater $v s$ food) needs to be 
characterised. In this respect, a set of laboratory experiments using radiotracer techniques has been planned to explore the "dietary contamination pathway" hypothesis. Our results also allowed speculating on the occurrence of different accumulation/detoxification strategies of various metals (i.e. $\mathrm{Ag}, \mathrm{Mn}$ and $\mathrm{Zn}$ ) within the Pectinidae family. Finally, a preliminary estimation of trace element exposure to humans through scallop consumption has warned consumers about the possible health risks linked to elevated As accumulation by $C$. radula.

Acknowledgements. The IAEA is grateful for the support provided to its Marine Environment Laboratories by the Government of the Principality of Monaco. Authors gratefully thank O. Pringault (IRD-Noumea) for his help during the fieldwork and C. Churlaud (CCA, Univ. La Rochelle) for her participation in the analytical process. MW is an Honorary Senior Research Associate of the National Fund for Scientific Research (NFSR, Belgium). This work was supported by the IAEA, the CRELA (Univ. La Rochelle) and the PNEC Programme (Chantier Nouvelle-Calédonie).

\section{$\underline{\text { References }}$}

Ambastian, P., Fernex, F., Bernat, M., Parron, C., Lecolle J., 1997. High metals inputs to closed seas: the New Caledonia lagoon. Journal of Geochemical Exploration 59, 59-74.

Andren, A.W., Bober T.W., 2002. Silver in the environment: transport, fate and effects. Society of Environment Toxicology and Chemistry. Pensacola, FL, USA.

Benson, A.A., Summons R.E., 1981. Arsenic accumulation in Great Barrier Reef invertebrates. Science 211, 482-483.

Berkman, P.A., Nigro M., 1992. Trace metal concentrations in scallops around Antarctica: Extending the Mussel Watch Programme to the Southern Ocean. Marine Pollution Bulletin 24, 322-323.

Bouchet P. Combien y a-t-il de mollusques en Nouvelle-Calédonie? Rossiniana 3, 12; 1979 
Brooks, R.R., Rumsby M.G., 1965. The biogeochemistry of trace element uptake by some New Zealand bivalves. Limnology and Oceanography 10, 521-527.

Bruland, K.D., 1983. Trace elements in seawater, in: Riley JP, Chester R (Eds.), Chemical oceanography. Academic Press, London, pp 157-201.

Bryan G.W., 1973. The occurrence and seasonal variation of trace metals in the scallops Pecten maximus (L.) and Chlamys opercularis (L.). Journal of the Marine Biological Association of the UK 53, 145-166.

Bustamante, P., Grigioni, S., Boucher-Rodoni, R., Caurant, F., Miramand P., 2000. Bioaccumulation of 12 trace elements in the tissues of the nautilus Nautilus macromphalus from New Caledonia. Marine Pollution Bulletin 40, 688-696.

Bustamante, P., Miramand P., 2004. Interspecific and geographical variations of trace element concentrations in Pectinidae from European waters. Chemosphere 57, 1355-1362.

Bustamante, P., Miramand P., 2005. Subcellular and body distributions of 17 trace elements in the variegated scallop Chlamys varia from the French coast of the Bay of Biscay. Science of the Total Environment 337, 59-73.

Chen, M., Dei, R.C.H., Wang, W.-X., Guo L., 2003. Marine diatom uptake of iron bound with natural colloids of different origins. Marine Chemistry 81, 177-189.

Dijkstra, H.H., Richer de Forges, B., Clavier, J., Lefort Y., 1990. Pectinidés des fonds meubles dans les lagons de Nouvelle-Calédonie et des Chesterfield. 2ème partie: systématique et biogéographie. Rossiniana 46, 3-10.

Fernandez, J.-M., Ouillon, S., Chevillon, C., Douillet, P., Fichez, R., Legendre R., 2006. A combined modelling and geochemical study of the fate of terrigenous inputs from mixed natural and mining sources in a coral reef lagoon (New Caledonia). Marine Pollution Bulletin $52,320-331$

Fattorini, D., Regoli F., 2004. Arsenic speciation in tissues of the Mediterranean polychaete Sabella spallanzanii. Environmental Toxicology and Chemistry 23: 1881-1887. 
Francesconi, K.A., Moore, E.J., Joll M.L., 1993. Cadmium in the saucer scallop, Amusium balloti, from Western Australian water: concentrations in adductor muscle and redistribution following frozen storage. Australian Journal of Marine and Freshwater Research 44, 787-797. George, S.G., Pirie, B.J.S., Coombs T.L., 1980. Isolation and elemental analysis of metal-rich granules from kidney of the scallop Pecten maximum (L.). Journal of Experimental Marine Biology and Ecology 42, 143-156.

Goldberg E.D., 1995. Emerging problems in the coastal zone for the twenty-first century. Marine Pollution Bulletin 31, 152-158.

Hédouin L., 2006. Caractérisation d'espèces bioindicatrices pour la surveillance des activités minières et la gestion de l'environnement en milieu récifal et lagonaire: application au lagon de la Nouvelle-Calédonie. PhD Thesis, La Rochelle University, France.

Hédouin, L., Pringault, O., Metian, M., Bustamante, P., Warnau M., 2007. Nickel bioaccumulation in bivalves from the New Caledonia lagoon: Seawater and food exposure. Chemosphere 66, 1449-1457.

Ishii, T., Nakamura, R., Ishakawa, M., Koyanagi T., 1985. Determination and distribution of trace elements in marine invertebrates. Bulletin of The Japanese Society of Scientific Fisheries 51, 609-617.

Jaquet S., 2005. Impact des apports en nutriments sur le réseau trophique planctonique du lagon sud-ouest de la Nouvelle-Calédonie. PhD Thesis, Nouvelle-Calédonie.

JECFA (Joint Expert Committee on Food Additives), 2006. JECFA Evaluations - Cadmium. TRS 930-JECFA 64/26.

Labrosse, P., Fichez, R., Farman, R., Adams T., 2000. New Caledonia, in: Sheppard CRC (Eds.), Seas at the Millennium: An environmental evaluation. Elsevier Science, Amsterdam, pp 723-736.

Lai, V.W.-M., Cullen, W.R., Ray S., 1999. Arsenic speciation in scallops. Marine Chemistry $66,81-89$. 
Lefort Y., 1994. Growth and mortality of the tropical scallops: Annachlamys flabellata (Bernardi), Comptopallium radula (Linne) and Mimachlamys gloriosa (Reeve) in South-West Lagoon of New Caledonia. Journal of Shellfish Research 13, 539-546.

Lemonnier, H., Faninoz S., 2006. Effect of water exchange on effluent and sediment characteristics and on partial nitrogen budget in semi-intensive shrimp ponds in New Caledonia. Aquaculture Research 37, 938-948.

Luoma, S.N., Bo, Y.B., Bryan G.W., 1995. Fate, bioavailability and toxicity of silver in estuarine environments. Marine Pollution Bulletin 31, 44-54.

Mauri, M., Orlando, E., Nigro, M., Regoli F., 1990. Heavy metals in the Antarctic scallop Adamussium colbecki. Marine Ecology Progress Series 67, 27-33.

Monniot, F., Martoja, R., Monniot C., 1994. Cellular sites of iron and nickel accumulation in ascidians related to the naturally and anthropic enriched New Caledonian environment. Annales de l'Institut Océanographique 70, 205-216.

Neff J.M., 1997. Ecotoxicology of arsenic in the marine environment. Environmental Toxicology and Chemistry 16, 917-927.

Nigro, M., Orlando, E., Regoli F., 1992. Ultrastructural localization of metal binding sites in the kidney of the Antarctic scallop Adamussium colbecki. Marine Biology 113, 637-643.

Palmer, J., Rand G., 1977. Trace metal concentrations in two shellfish species of commercial importance. Bulletin of Environmental Contamination and Toxicology 18, 512-520.

Pesch, G.G., Renolds, B., Rogerson P., 1977. Trace metals in scallops from within and around two ocean disposal sites. Marine Pollution Bulletin 8, 224-228.

Peters, E.C., Gassman, N.J., Firman, J.C., Richmond, R.H., Power E.A., 1997. Ecotoxicology of tropical marine ecosystems. Environmental Toxicology and Chemistry 16, 12-40.

Rainbow P.S., 1995. Biomonitoring of heavy metal availability in the marine environment. Marine Pollution Bulletin 31, 183-192.

Rainbow, P.S., Phillips D.J.H., 1993. Cosmopolitan biomonitors of trace metals. Marine Pollution Bulletin 26, 593-601. 
Segar, D.A., Collins, J.D., Riley J.P., 1971. The distribution of the major and some minor elements in marine animals. Part II. Molluscs. Journal of the Marine Biological Association of the UK 51, 131-136.

Smedley, P.L., Kinniburgh D.G., 2002. A review of the source, behaviour and distribution of arsenic in natural waters. Applied Geochemistry 17, 517-568.

Ünlü, M.Y., Fowler S.W., 1979. Factor affecting the flux of arsenic through the mussel Mytilus galloprovincialis. Marine Biology 51, 209-219.

Uthe, J.F., Chou C.L., 1987. Cadmium in sea scallop (Plactopecten magellanicus) tissues from clean and contaminated areas. Canadian Journal of Fisheries and Aquatic Sciences 44, 91-98.

Viarengo, A., Canesi, L., Massu-Cotelli, A., Ponzano, E., Orunesu M., 1993. Cu, Zn, Cd content in different tissues of the Antarctic scallop Adamussium colbecki (Smith 1902): role of metallothionein in the homeostasis and in the detoxification of heavy metals. Marine Environmental Research 35, 216-217.

Warnau, M., Biondo, R., Temara, A., Bouquegneau, J-M., Jangoux, M., Dubois P., 1998. Distribution of heavy metals in the echinoid Paracentrotus lividus from the Mediterranean Posidonia oceanica ecosystem: seasonal and geographical variations. Journal of Sea Research 39, 267-280.

Warnau, M., Gómez-Batista, M., Alonso-Hernández, C., Regoli F., 2007. Arsenic: Is it worth monitoring in the Mediterranean Sea? Marine Sciences and Public Health - Some Major Issues. CIESM Workshop Monographs n³1, Monaco, pp 83-86.

Whicker, F.W., Schultz V, 1982. Radioecology: nuclear energy and the environment. Raton B, CRC Press, Florida.

WHO (World Health Organisation), 1989. Environmental Health Criteria 18 - Arsenic. World Health Organization, Geneva.

Zar J.H., 1996. Biostatistical analysis, Upper Saddle River, NJ, USA. 

Table 1. Concentration factor (mean $\pm \mathrm{SD} ; \mathrm{n}=4$ ) of the radiotracers in the different body compartments of Comptopallium radula after $4 \mathrm{~d}$ of seawater exposure.

\begin{tabular}{lrllccccccccc}
\hline Compartment & \multicolumn{2}{c}{${ }^{109} \mathbf{C d}$} & \multicolumn{2}{c}{${ }^{57} \mathbf{C o}$} & \multicolumn{2}{c}{${ }^{54} \mathbf{M n}$} & \multicolumn{2}{c}{${ }^{65} \mathbf{Z n}$} \\
\hline Digestive gland & 107 & \pm & 29 & 9.7 & \pm & 4.1 & 29 & \pm & 11 & 549 & \pm & 92 \\
Kidneys & 391 & \pm & 69 & 603 & \pm & 298 & 33 & \pm & 12 & 184 & \pm & 52 \\
Gonad & 76 & \pm & 75 & 3.1 & \pm & 1.8 & 14 & \pm & 6 & 55 & \pm & 14 \\
Muscle & 7.0 & \pm & 1.9 & 0.6 & \pm & 0.3 & 2.0 & \pm & 0.4 & 18 & \pm & 5.3 \\
Gills & 142 & \pm & 29 & 3.2 & \pm & 0.5 & 24 & \pm & 5.3 & 96 & \pm & 25 \\
Remaining tissues & 3.2 & \pm & 0.6 & 0.2 & \pm & 0.1 & 0.6 & \pm & 0.2 & 4.2 & \pm & 0.9 \\
\hline
\end{tabular}


Table 2. Metal distribution (mean $\% \pm \mathrm{SD}$, wet wt basis; $\mathrm{n}=4$ ) between shell and soft parts; and within the soft parts of Comptopallium radula after $4 \mathrm{~d}$ of seawater exposure.

\begin{tabular}{|c|c|c|c|c|c|c|c|c|c|c|c|c|}
\hline \multirow{2}{*}{$\begin{array}{l}\text { Compartment } \\
\text { Shell }\end{array}$} & \multicolumn{3}{|c|}{${ }^{109} \mathrm{Cd}$} & \multicolumn{3}{|c|}{${ }^{57} \mathrm{Co}$} & \multicolumn{3}{|c|}{${ }^{54} \mathrm{Mn}$} & \multicolumn{3}{|c|}{${ }^{65} \mathrm{Zn}$} \\
\hline & 31 & \pm & 6 & 92 & \pm & 4 & 96 & \pm & 1 & 42 & \pm & 9 \\
\hline Soft parts & 69 & \pm & 6 & 8 & \pm & 4 & 4 & \pm & 1 & 58 & & 9 \\
\hline Digestive gland & $-\overline{25}$ & \pm & $\overline{7}$ & 9.2 & $\overline{ \pm}$ & $-\overline{2.4}$ & $-\overline{3}$ & & $\overline{7}$ & $\frac{-5}{65}$ & & -3 \\
\hline Kidneys & 13 & \pm & 1 & 81 & \pm & 4.9 & 5.6 & \pm & 1.7 & 3.2 & \pm & 0.6 \\
\hline Gonad & 14 & \pm & 11 & 2.5 & \pm & 0.6 & 14 & \pm & 4 & 5.8 & \pm & 1.2 \\
\hline Muscle & 8.3 & \pm & 1.0 & 2.8 & \pm & 1.2 & 12 & \pm & 1 & 11 & \pm & 1.9 \\
\hline Gills & 38 & \pm & 7 & 3.9 & \pm & 1.7 & 33 & \pm & 7 & 13 & \pm & 1.8 \\
\hline Remaining tissues & 2.2 & \pm & 0.3 & 0.8 & \pm & 0.5 & 2.2 & \pm & 0.4 & 1.5 & \pm & 0.3 \\
\hline
\end{tabular}


Table 3. Element concentrations (mean $\pm \mathrm{SD} ; \mu \mathrm{g} \mathrm{g}^{-1}$ dry wt; $\mathrm{n}=5$ ) in sediment from the two sampling locations.

\begin{tabular}{cccccccc}
\hline & \multicolumn{3}{c}{ Maa Bay } & \multicolumn{3}{c}{ Sainte- Marie Bay } \\
\hline Ag & \multicolumn{3}{c}{$<$ dl* } & \multicolumn{3}{c}{$<$ dl* $^{*}$} \\
As & 6.4 & \pm & 0.3 & 5.8 & \pm & 0.2 \\
Cd & 1.0 & \pm & 0.2 & & $<$ & d.1.* \\
Co & 4.6 & \pm & 2.3 & 1.9 & \pm & 0.1 \\
Cr & 44 & \pm & 8 & 15 & \pm & 1 \\
Cu & 11 & \pm & 3 & 0.8 & \pm & 0.1 \\
Mn & 132 & \pm & 8 & 33 & \pm & 3 \\
Ni & 64 & \pm & 13 & 12 & \pm & 1 \\
$\mathbf{Z n}$ & 15 & \pm & 3 & 3.9 & \pm & 0.1 \\
\hline
\end{tabular}

*dl : detection limit 
Table 4. Element concentrations (mean $\pm \mathrm{SD}$ and min-max values, $\mu \mathrm{g} \mathrm{g}^{-1} \mathrm{dry} \mathrm{wt} ; \mathrm{n}=5$ ) in tissues and organs of the scallop Comptopallium radula from two stations in the South-West lagoon of New Caledonia.

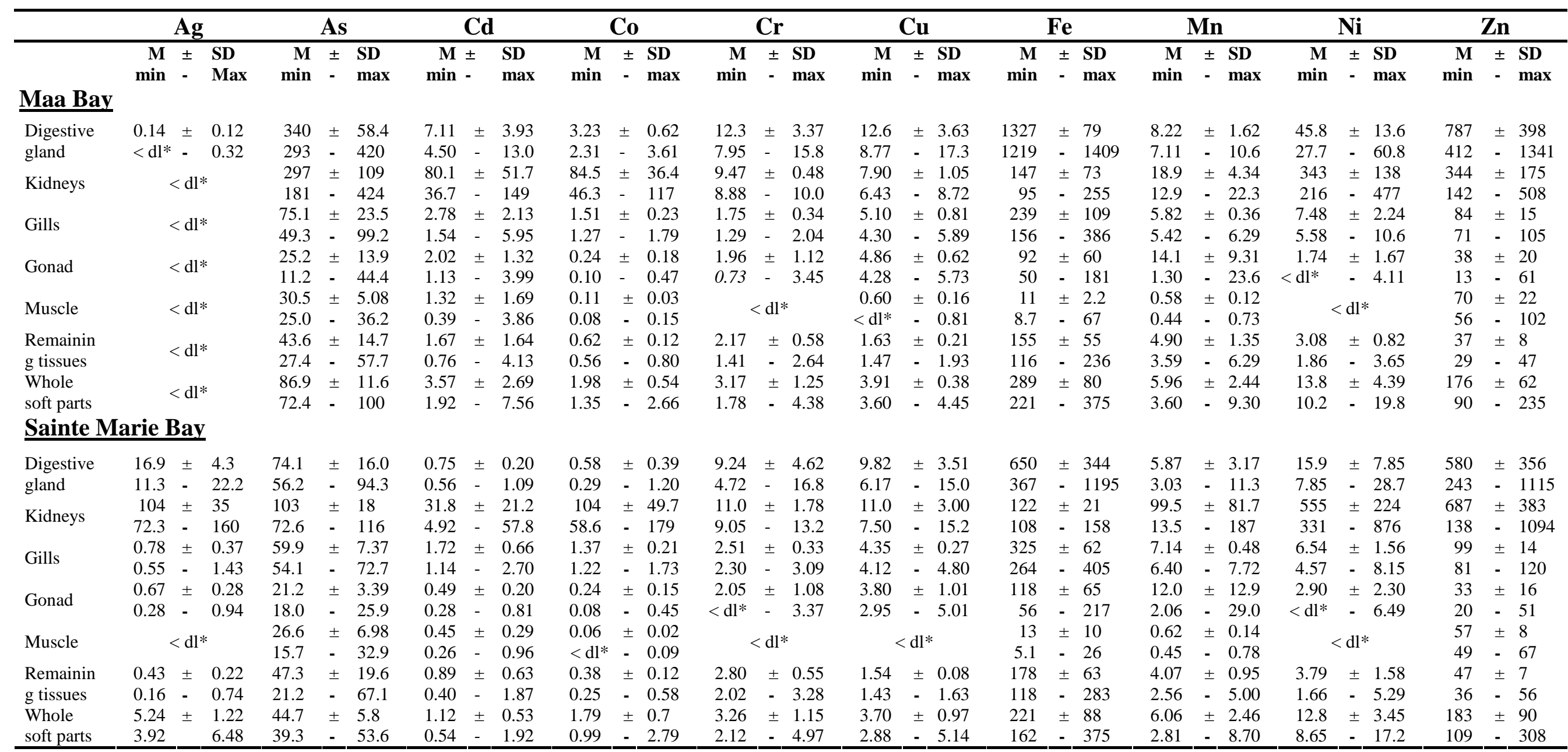

$* d l$ : detection limit 
Table 5. Mean element content $(\mu \mathrm{g})$ in scallops from the two sampling stations and number of individuals to be eaten to reach the PMTDI and the PTWI for women $(50 \mathrm{~kg})$ and men $(80 \mathrm{~kg})$.

\begin{tabular}{cccccccc}
\hline & \multicolumn{2}{c}{ Element content in $\boldsymbol{C}$. radula $(\boldsymbol{\mu g})$} & & \multicolumn{3}{c}{ Number of scallops to reach PMTDI or } \\
PTWI
\end{tabular}


Table 6. $\mathrm{Co}, \mathrm{Cu}, \mathrm{Mn}$, and $\mathrm{Zn}$ concentrations (Mean $\pm \mathrm{SD} ; \mu \mathrm{g} \mathrm{g}{ }^{-1} \mathrm{dwt}$ ) in kidneys from different scallop species

\begin{tabular}{|c|c|c|c|c|c|c|}
\hline Species & Co & $\mathrm{Cu}$ & Mn & $\mathbf{Z n}$ & Sampling & References \\
\hline Aequipecten & - & $507 \pm$ & - & 31053 & Bay of & Bustamante and \\
\hline A. opercularis & - & $106 \pm$ & - & $6632 \pm$ & Faroe Island & Bustamante and \\
\hline A. opercularis & $15.1 \pm$ & 1285 & 17300 & 40800 & English & Bryan 1973 \\
\hline Chlamys varia & - & $142 \pm$ & $\begin{array}{c}1.1 E 7 n \\
-\end{array}$ & 24107 & Bay of & Bustamante and \\
\hline Pecten jacobeus & & $17.5 \pm$ & $6390 \pm$ & $2790 \pm$ & Adriatic sea & Mauri et al. 1990 \\
\hline P. novae- & - & - & 2660 & 2630 & New & Brooks and \\
\hline P. maximus & - & $\begin{array}{c}13.5 \pm \\
n \cap\end{array}$ & 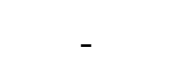 & $72278 \pm$ & Bay of & Bustamante and \\
\hline P. maximus & $\begin{array}{c}9.05 \pm \\
2 \times 7\end{array}$ & $\begin{array}{l}20.8 \\
\ln 2\end{array}$ & $\begin{array}{l}15300 \\
1 \quad 1 \mathrm{nn}\end{array}$ & $\begin{array}{l}19300 \\
1 \quad 1 \text { onn }\end{array}$ & English & Bryan 1973 \\
\hline P. maximus & - & $\begin{array}{c}117 \pm \\
1 \mathrm{nn}\end{array}$ & $\begin{array}{c}17811 \pm \\
11 \text { กาo }\end{array}$ & $\begin{array}{c}32766 \pm \\
11 \text { กาo }\end{array}$ & Scotland & George et al. 1980 \\
\hline Patinopecten & $0.35 \pm$ & $5.4 \pm$ & $10 \pm 5$ & $174 \pm$ & Japan & Ishii et al. 1985 \\
\hline Adamussium & - & $\begin{array}{c}4.0 \pm \\
17\end{array}$ & $\begin{array}{c}16.3 \pm \\
\text { on }\end{array}$ & $\begin{array}{c}199 \pm \\
\text { on }\end{array}$ & Antarctic & Mauri et al. 1990 \\
\hline Comptopallium & $\begin{array}{c}84 \pm \\
26\end{array}$ & $\begin{array}{c}7.9 \pm \\
1 \cap\end{array}$ & $\begin{array}{c}18.9 \pm \\
12\end{array}$ & $\begin{array}{c}344 \pm \\
175\end{array}$ & Maa Bay & Present study \\
\hline C. radula & $\begin{array}{c}104 \pm \\
\text { En }\end{array}$ & $11 \pm 3$ & $\begin{array}{c}100 \pm \\
\text { on }\end{array}$ & $\begin{array}{c}687 \pm \\
\text { ก0ว }\end{array}$ & $\begin{array}{l}\text { Sainte } \\
\boldsymbol{n}_{\boldsymbol{n}} \ldots:-\mathbf{n} \ldots\end{array}$ & Present study \\
\hline
\end{tabular}




\section{Captions to Figures}

Figure 1. Sampling locations along the SW coast of New Caledonia.

Figure 2. Whole-body uptake kinetics of ${ }^{109} \mathrm{Cd},{ }^{57} \mathrm{Co},{ }^{54} \mathrm{Mn}$ and ${ }^{65} \mathrm{Zn}$ in Comptopallium radula (mean concentration factor, $\mathrm{CF} \pm \mathrm{SD} ; \mathrm{n}=4)$ and the corresponding linear model $(\mathrm{p}<0.0001)$.

Figure 3. Comparison of trace element distribution (mean $\% \pm \mathrm{SD}$; dry wt basis; $\mathrm{n}=5$ ) in tissues and organs of Comptopallium radula from Maa Bay (white bars) and Sainte Marie Bay (dark grey bars). Significant differences between stations are indicated by $*(\mathrm{p}<0.05), * *$ $(\mathrm{p}<0.01)$ or $* * *(\mathrm{p}<0.005)$. 


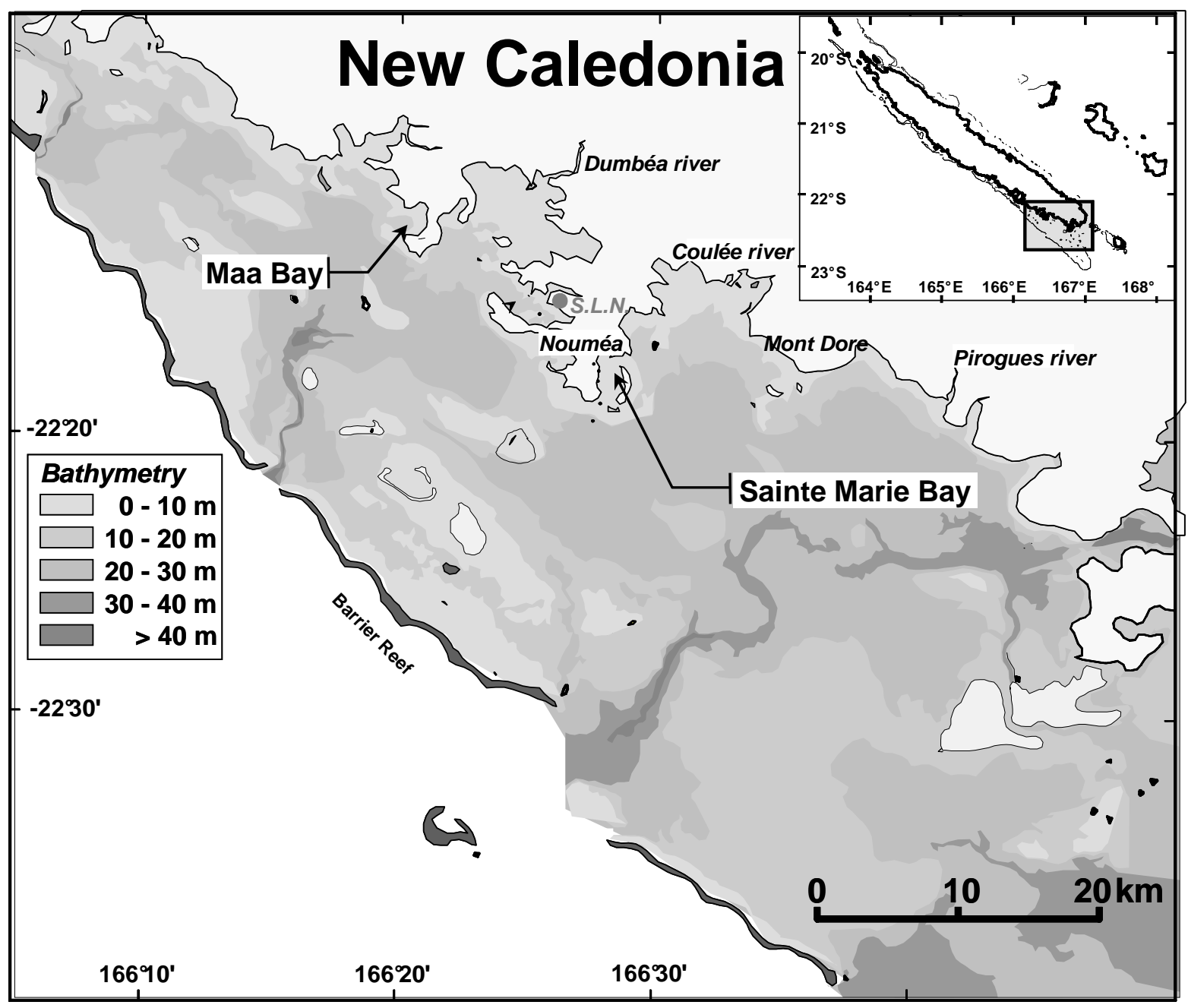

Fig. 1 


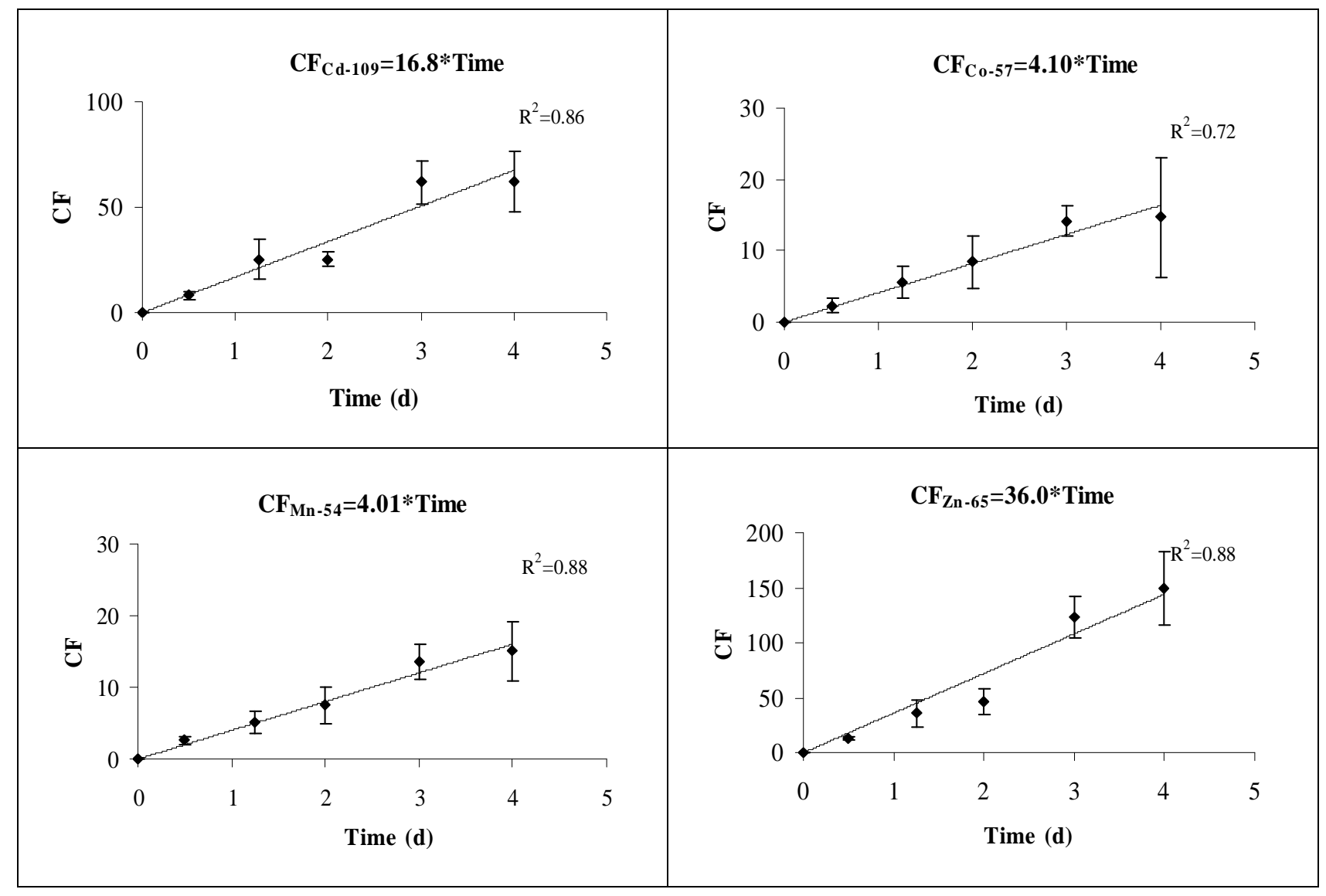

Fig. 2 

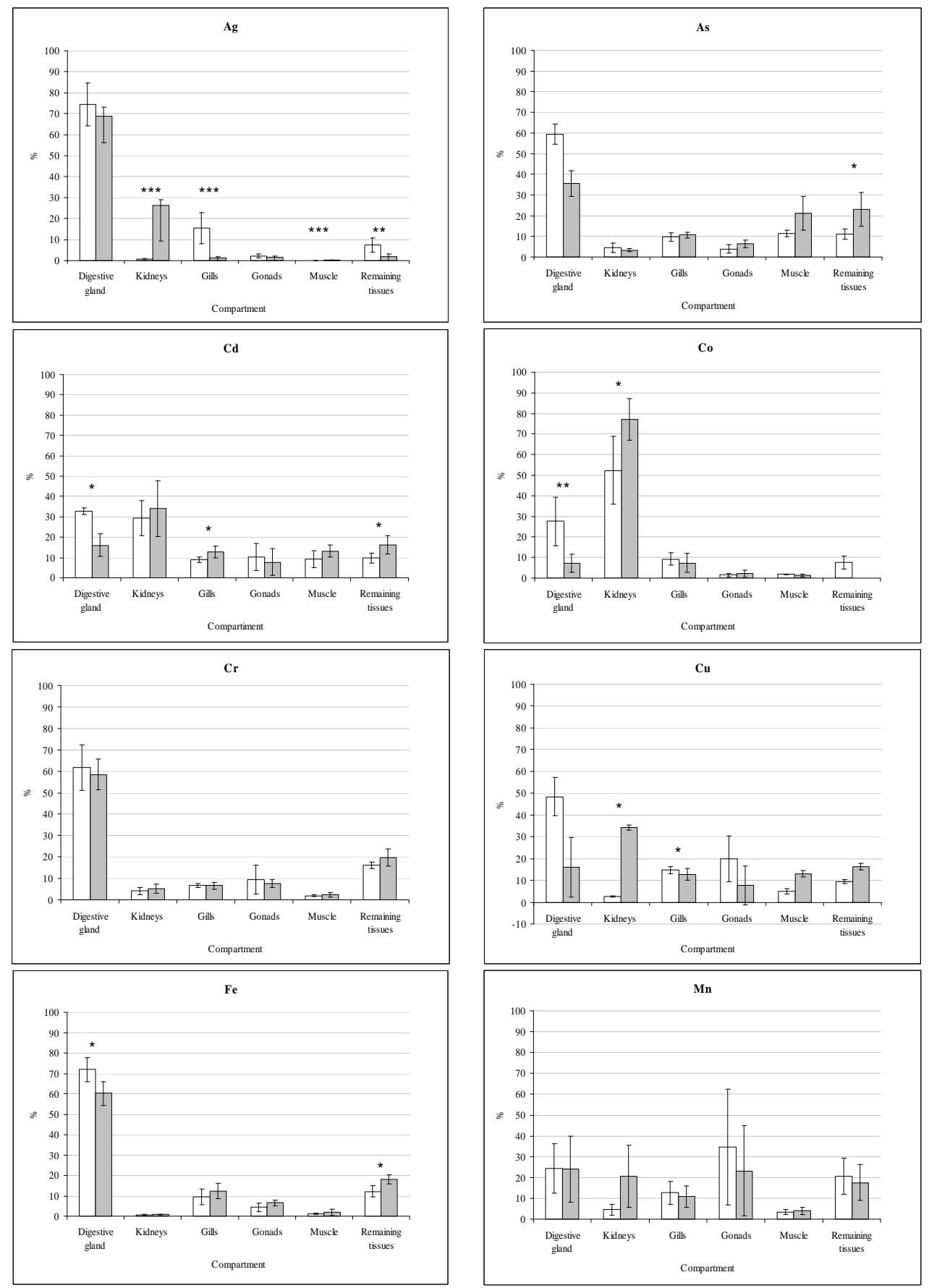

Fig. 3 